\title{
PENGARUH LATIHAN LOMPAT RINTANGAN MERAIH SASARAN DIATAS TERHADAP KEMAMPUAN LOMPAT JAUH GAYA GANTUNG PADA SISWA KELAS V DI SDN TOMO KECAMATAN TOMO KABUPATEN SUMEDANG
}

\author{
Maya Nurhayati ${ }^{1}$ dan Dea Hildawati ${ }^{2}$ \\ Universitas Majalengka, Indonesia \\ mnurhayati388@gmail.com
}

\begin{abstract}
ABSTRAK. Penelitian ini bertujuan untuk mengetahui keterampilan lompatan siswa dengan hasil lompat jauh gaya gantung pada siswa kelas V SD Negeri Tomo pada semester genap Tahun pelajaran 2018/2019. Penelitian ini merupakan penelitian eksperimen dengan desain penelitian pre-test dan post-test. Subjek dari pebelitian ini adalah siswa laki-laki kelas V SD Negeri Tomo dengan jumlah sampel 20 siswa. Metode penelitian ini menggunakan metode eksperimen dengan desain penelitian one group pretest-posttest dan rancangan penelitian menggunakan rubrik penilaian kemampuan lompat jauh gaya gantung pada siswa kelas $\mathrm{V}$ pada semester genap Tahun pelajaran 2018/2019 dengan sampel penelitiannya yaitu siswa kelas V yang berjumlah 20 siswa. Hasil penelitian menunjukan bahwa nilai tertinggi yang diperoleh siswa pada saat pretest adalah 65 dan nilai terendah adalah 30, untuk hasil lompat jauh yang diperoleh siswa pada saat posttest tertinggi 100 dan terendah adalah 75. Pengujian hipotesis bertujuan untuk membuktikan diterima atau tidaknya hipotesis yang secara statistik dijelaskan sebagai berikut: Hipotesis Nol (Ho) mengatakan bahwa tidak ada pengaruh latihan lompat rintangan meraih sasaran diatas terhadap kemampuan lompat jauh gaya gantung di SD Negeri Tomo. Hipotesis Alternatif (Ha) mengatakan bahwa ada pengaruh latihan lompat rintangan meraih sasaran diatas terhadap kemampuan lompat jauh gaya gantung di SD Negeri Tomo. Berdasarkan hasil analisis terlihat bahwa uji-t dalam latihan lompat rintangan meraih sasaran diatas memiliki nilai t hitung 23,819 dan nilai tabel dengan $\mathrm{db}=19$ pada taraf signifikan 0,05 sebesar 6,499. Nilai $\mathrm{t}$ hitung $>\mathrm{t}$ tabel, maka dapat disimpulkan bahwa Ho ditolak dan Ha diterima, berarti ada pengaruh latihan lompat rintangan meraih sasaran diatas terhadap kemampuan lompat jauh gaya gantung di SD Negeri Tomo.
\end{abstract}

Kata Kunci: Keterampilan Lompatan; Hasil Lompat Jauh; Latihan Rintangan Meraih Sasaran Diatas

\section{Pendahuluan}

Atletik adalah cabang olahraga yang banyak digemari oleh masyarakat di seluruh dunia, tidak terkecuali di Indonesia. Hal ini dapat dilihat dengan banyaknya masyarakat yang ikut serta dalam setiap kegiatan olahraga Atletik yang diselenggarakan, baik dalam bentuk pertandingan tingkat Kecamatan hingga tingkat dunia, seperti Popda, Porseni atau Olimpiade. Olahraga Atletik dapat dilakukan mulai dari anak-anak hingga orang dewasa dan dapat dilakukan di dalam maupun di luar ruangan. Salah satu bahan pengajaran yang diajarkan di sekolah dasar yaitu atletik, karena olahraga atletik merupakan salah satu mata pelajaran yang wajib diajarkan pada siswa di Sekolah Dasar (SD). 
Menurut Purnomo (2011) menyatakan bahwa pengertian atletik adalah: "aktivitas atau kegiatan jasmani yang terdiri atas gerakan-gerakan dasar yang harmonis dan juga dinamis, yakni jalan, lari, lempar serta lompat”. Keempat nomor lompat tersebut yang akan dibahas lebih lanjut adalah pada nomor lompat jauh. Lompat jauh adalah salah satu nomor lompat dari cabang olahraga atletik. Dalam lompat jauh terdapat beberapa macam gaya atau sikap badan pada saat melayang di udara, Purnomo (2007) macam-macam gaya lompat jauh adalah gaya jongkok (sail style), gaya menggantung (hang style), dan gaya berjalan di udara (hitch kick style). Gaya lompat yang paling sederhana untuk diajarkan pada pemula seperti siswa di SD adalah lompat jauh gaya gantung.

Berdasarkan pengamatan selama pra observasi terdapat beberapa fakta bahwa sebagian besar siswa hasil lompat jauh tidak maksimal hal ini disebabkan oleh faktor fisik, teknik, taktik dan mental yang tidak mendapat perhatian yang serius baik siswa maupun guru, dari beberapa komponen tersebut menurut Syarifuddin (1992) menyatakan bahwa: "komponen yang sangat besar pengaruhnya terhadap hasil lompatan pada lompat jauh adalah kekuatan otot tungkai yang meliputi: kecepatan yaitu pada awalan dan kekuatan yaitu pada tolakan". "Perpaduan antara kecepatan dan kekuatan dinamakan power atau daya otot" (Sajoto, 1988).

Usaha untuk meningkatkan power dibutuhkan latihan yang disesuaikan dengan kemampuan atlet, sebab atlet dari masing-masing cabang baik dari cabang yang sama dan bahkan dari cabang berbeda yang memiliki kemampuan yang berlainan. Dengan demikian perlu dicari bentuk latihan yang tepat dan efektif untuk meningkatkan power ototnya terutama pada kemampuan melompat adalah kekuatan otot-otot pada tungkai.

Menurut Syarifuddin dan Muhadi (1992) latihan pembentukan daya ledak anak usia SD dapat dilakukan dengan latihan lompat jauh tanpa awalan, lompat setinggi-tingginya meraih suatu benda yang tergantung diatas, dan bentuk latihan yang dapat meningkatkan kekuatan otot kaki menurut Carr (2000) adalah dengan melompat rintangan rendah dan menyundul bola. Sedangkan menurut Bernhard (1993) bentuk-bentuk permainan dan latihan untuk melatih melompat pada lompat jauh yaitu loncatan-loncatan dengan menyentuh suatu penentu selama mungkin memegang teguh sikap tubuh bagian atas yang tegak, penentu arah selalu diambil dari tempat pendaratan. untuk menunjang prestasi yang belum diraih maka peneliti ingin meningkatkan prestasi lompat jauh dengan menggunakan model latihan yang dapat meningkatkan kemampuan lompat jauh.

Salah satunya dengan latihan rintangan meraih sasaran diatas. Karena latihan tersebut mengandung unsur fisik, teknik, taktik dan mental yang berguna untuk meningkatkan daya ledak atau power terutama power otot tungkai yang sangat penting dalam gerakan 
menumpu dan menolak sehingga hasil lompat jauh gaya gantung dapat dicapai lebih maksimal, adapun dalam pelaksanaan latihannya siswa berdiri sambil berbaris menghadap kardus yang sudah disiapkan kemudian secara bergiliran melompati kardus tersebut sambil menjangkau sasaran bola yang ada diatas. Sehingga penulis tertarik mengambil judul penelitian "Pengaruh Latihan Lompat Rintangan Meraih Sasaran Diatas Terhadap Kemampuan Lompat Jauh Gaya Gantung Pada Siswa Kelas V di SDN Tomo Kecamatan Tomo Kabupaten Sumedang”.

\section{Metode Penelitian}

Metode yang digunakan menggunakan metode ekperimen dengan desain penelitian desain one group pretest-posttest. penelitian yang dilakukan menurut desain one group pretest-posttest adalah diberikannya pretest $(\mathrm{O} 1)$, dalam penelitian ini tes yang diberikan pada subjek penilaian adalah tes lompat jauh gaya gantung untuk mengetahui tingkat keterampilan gerak dasar lompat jauh gaya gantung subjek penelitian. Setelah diberikan pretest maka subjek penelitian diberikan perlakuan (X), dalam penelitian ini perlakuan yang diberikan adalah lompat rintangan meraih sasaran diatas. Setelah diberikan perlakuan dalam beberapa pertemuan, maka subjek penelitian diberikan posttest $(\mathrm{O} 2)$ yaitu tes lompat jauh gaya gantung untuk mengetahui perubahan tingkat keterampilan gerak dasar lompat jauh gaya gantung. Hasil dari perlakuan akan dilihat dengan membandingkan hasil pretest dan posttest.

Populasi dan sampel yang digunakan yakni sdmua kelas atas kelas V yang berjumlah 20 orang. Tes yang digunakan adalah tes lompat jauh gaya gantung. Tes dan pengukuran dalam penelitian ini dilaksanakan untuk mendapatkan data tentang hasil lompat jauh gaya gantung yang dilaksanakan dua kali yaitu pre-test dan post-test. Hasil tes dicatat dalam satuan centimeter.

\section{Hasil dan Pembahasan (12 pt)}

Hasil analisis statistik deskriptif pretest untuk keterampilan dan hasil lompat jauh gaya gantung di dapat nilai minimal $=30$, nilai maksimal $=65$, rata-rata $=48$, nilai tengah $=50$, dengan standar deviasi $=9,6$. Hasil analisis statistik deskriptif posttest untuk keterampilan dan hasil lompat jauh gaya gantung di dapat nilai minimal $=75$, nilai maksimal $=100$, rata- rata $=87,5$, nilai tengah $=85$, dengan standar deviasi $=8$. 
Tabel 1

Deskriptif Statistik Pretest dan Posttest lompat jauh gaya gantung

\begin{tabular}{|c|c|c|}
\hline Statistik & Pretest & Posttest \\
\hline $\mathrm{N}$ & 20 & 20 \\
\hline Mean & 48 & 85,5 \\
\hline Median & 50 & 85 \\
\hline Std. Deviasi & 9,6 & 8 \\
\hline Minimum & 30 & 75 \\
\hline Maximum & 65 & 100 \\
\hline
\end{tabular}

Siswa yang diberi latihan lompat rintangan meraih sasaran diatas lebih senang dan antusias dalam mengikuti latihan. Latihan adalah suatu proses atau dinyatakan dengan kata lain periode waktu yang berlangsung selama beberapa waktu sampai siswa tersebut mencapai standar penampilan yang tinggi. Selain itu, Menurut Harsono yang dikutip oleh Trimanto (2010), menyatakan bahwa prestasi dapat meningkat, latihan haruslah berpedoman pada teori serta prinsip latihan yang benar dan sudah diterima secara universal. Tanpa berpedoman pada perinsip latihan serta teori yang benar latihan sering kali menjurus ke praktik mala-latihan dan latihan yang tidak sisrematis dan metodis sehingga peningkatan prestasi sukar dicapai. Setelah diberikan latihan selama 8 kali pertemuan dengan menggunakan prinsipprinsip latihan seperti, persiapan, adaptasi, beban berlebih, progresif, spesifikasi, pariasi, pemanasan, pendinginan, dan sistematik.

Maka keterampilan lompat jauh gaya gantung pada siswa kelas V di SD Negeri Tomo semakin meningkat. Sebelum diberikan latihan lompat rintangan meraih sasaran diatas sebagian besar keterampilan lompat jauh siswa di SD Negeri Tomo berada pada rata-rata 48 dengan standar deviasi 9,6. Hal ini disebabkan kurangnya intensitas latihan baik dengan latihan lompat rintangan meraih sasaran diatas. Kondisi ini membuat keterampilan lompat jauh siswa kurang baik.

Setelah mendapat perlakuan berupa latihan lompat rintangan meraih sasaran diatas, ternyata kemampuan mereka mengalami peningkatan yang signifikan, hal ini terlihat dari rerata keterampilan lompat jauh menjadi 87,5 dengan standar deviasi 8. Hal ini menunjukan bahwa latihan lompat rintangan meraih sasaran diatas memberikan pengaruh terhadap kemampuan lompat jauh siswa.

\section{Kesimpulan}

Sebelum diberikan latihan lompat meraih sasaran diatas, kemampuan lompat jauh gaya gantung bisa berada pada rerata 48. Kemudian setelah mendapatkan perlakuan dengan latihan lompat meraih sasaran diatas, rerata kemampuan lompat jauh gaya gantung sebesar 87,5. 
Berdasarkan analisis hasil dan pembahasan, dapat disimpulkan bahwa latihan lompat meraih sasaran diatas mempunyai pengaruh secara signifikan terhadap kemampuan lompat jauh gaya gantung di SD Negeri Tomo.

\section{Daftar Pustaka}

Bernhard, G. (1993). Atletik Prinsip Dasar Latihan Loncat Tinggi, Jauh, Jangkit dan Loncat Galah. Terjemahan dari String Trainning voor.Djeugd.Semarang: Dahara Prize.

Carr, G. (2000). Atletik (Edisi Terjemahan). Jakarta : PT. Raja Grafindo Persada.

Depdikbud. (2004). Kurikulum 2004 Standar Kompetensi SD dan MI. Jakarta: Dharma Bhakti.

Depdiknas. (2000). Pedoman dan Modal Pelatihan Kesehatan Olah Raga Bagi Pelatih Olahragawan Pelajar. Jakarta.

Harsono. (1982). Ilmu Coaching. Jakarta: KONI Pusat.

IAAF. (2000). Pedoman Mengajar Lari, Lompat, Lempar level I. Jakarta: Gaung Persada Press.

KONI. (2000). Panduan Kepelatihan. Jakarta: KONI

Kosasih .(1985). Olahraga Tehnik dan Program Latihan. Jakarta. Akademika Pressindo.

Matakupan. (1996). Teori Bermain. Jakarta: Depdikbud.

Nurhasan. (2001). Tes dan Pengukuran dalam Pendidikan Jasmani. Jakarta: Depdiknas.

Poerwodarminto.(1984). Kamus Umum Bahasa Indonesia.Jakarta : Depdikbud.

Purnomo, E. Dkk. (2011) Dasar-dasar Gerak Atletik. Alfamedia. Yogyakarta.

Rubianto, H. (2003). Ilmu Kepelatihan Dasar. Semarang : FIK UNNES.

Sajoto. (1988). Peningkatan dan Pembinaan Kekuatan Kondisi Fisik dalam Olahraga. Semarang : Dahara Prize.

Soedarminto dan Soeparman. (1993). Materi Pokok Kinesiologi. Jakarta.

Sugiono. (2012). Metode Penelitian Kuantitatif Kualitatif dan R\&D. Edisi ke tujuh belas. Bandung: Alfabeta

Sugito dkk. (1994). Pendidikan Atletik. Jakarta : Depdikbud.

Syarifuddin dan Muhadi.(1992/1993).Pendidikan Jasmani dan Kesehatan.Jakarta: Depdikbud.

Syarifuddin. (1992). Atletik. Jakarta: Depdikbud. (1997). Kondisi Fisik Anak-anak Sekolah Dasar.Jakarta : Depdikbud. (2006). Statistik untuk penelitian.Bandung: Alfabeta 